\title{
Factors of Production Influencing Gross Domestic Product in Nepal
}

\author{
Prabhat Jha $^{1^{*}, \text { Shiva Chandra Dhakal }}{ }^{1}$

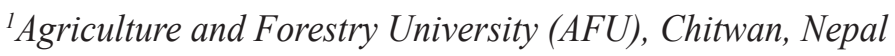

\section{*CORRESPONDENCE:}

Prabhat Jha

Agriculture and Forestry University

(AFU), Chitwan, Nepal

Email: afuprabhat@gmail.com

ISSN : 2382-5359(Online), 1994-1412(Print)

DOI:

https://doi.org/10.3126/njst.v20i1.39389

\section{ACCESS THE ARTICLE ONLINE}

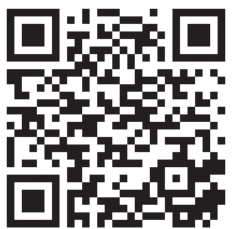

CONFILICT OF INTEREST: None

Copyright: The Author(s) 2020. This is an open

access article under the CC BY license.

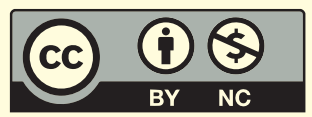

\begin{abstract}
This study has analysed the factors of production, viz; agricultural land, working force and gross fixed capital formation (GFCF) of Nepal between 2000/01-2017/18 AD and has determined their effects on national income, viz; Gross Domestic Product (GDP) by using CobbDouglas regression function. The results showed an average growth rate of GDP, agricultural land, working force and GFCF to be $3.9 \%$, $0.8 \%, 1.5 \%$ and $7.9 \%$, respectively, with the values plummeting in $2015 / 16$, due to occurrence of the devastating earthquake in 2015 , but then again variable values skyrocketed following years. The regression analysis found that GDP was affected significantly by agricultural land and working force, but insignificant with GFCF. On an average, with the increase in agricultural land and working force by $1 \%$, GDP increased by $1.1 \%$ and $1.7 \%$, respectively. Thus, policy regarding an increment of agricultural land use and employment of labour force must be framed to improve the Nepalese economy.
\end{abstract}

Keywords: Agriculture land, GDP, investment, population

\section{INTRODUCTION}

The country's labour and capital utilising its natural resources to produce a certain amount of goods and services annually is called National Income (Marshall 2009). Thereby, the total market value of all final goods and services produced annually by a country represents its National Income. Since the factors of production viz land, labour, capital and entrepreneurship produce the goods and services and they get their share of income via rent, wage, interest and profit, respectively, for accompanying the production of goods and services, the total of all those incomes received by the people of the country also represents national income (Ahuja 2018). According to Simon Kuznets, National income is defined as the net output of goods and services flowing during the year in the hands of ultimate consumers from the country's productive system. Thus, whatever the definition of national income, its essence lies in the money measure of the net value of all products and services of an economy during a year, counted without duplication, after having allowed for depreciation both in public and private sectors in consumption and capital goods sectors and finally throwing in the net gains from international transactions comprising of gains including from capital lent or invested 
abroad.

There are various national income concepts, and Gross Domestic Product (GDP) is the primary national accounting measure of the total output of goods and services. GDP is defined as the market value of all final goods and services produced during the accounting year within the country's domestic territory (Deepashree 2016). Either through product method, expenditure method or income method, the value of GDP calculated gives us the essence of national income (Ahuja 2018). Traditionally the higher the GDP means the economy is in good shape and the nation is moving forward and vice-versa, but today the debates account regarding real economic welfare or standard of living measurement by GDP(Gertner 2010). Although there are other measures of well-being, such as Green GDP, Index of Sustainable Economic Welfare, Genuine Progress Indicator, Happy Planet Index, Gross National Happiness and National Well-Being Accounts; they still do not reflect the impact of technology in our lives. Thus, the absence of perfect alternatives to determine real economic prosperity, GDP still lingers on to measure well- being of the society (Thoma 2016). Thus, in the end from the economic point of view, it is essential to know the major factors that determine the GDP to understand the economy better.

In the Nepalese Context, much of the research work on national income is focused on remittance and migration (Ojha, 2019; Sunam \& Mccarthy, 2015; Paudel, 2015; Maharjan \& Bauer, 2012 \& Seddon et al. 1998), very few research are confined to determine which of the domestic factors of production affects the GDP of the Nepalese Economy. The study of determinants of the country's national income could help the country achieve stability and growth by implementing appropriate fiscal and monetary policies (IMF 2001). This study is useful for macro-economists, researchers, and students by providing which factor of production determines the Nepalese economy by analysing the annual trend, growth rate trend and determinants of GDP.

\subsection{Review of Literature}

The labour force of Nepal is 16.81 million workers which ranks $38^{\text {th }}$ largest in the world(CIA, 2017), the arable area is 2.1 million hectares which ranks $79^{\text {th }}$ largest in the world (World Bank 2017) and the Gross Fixed Capital Formation (GFCF) is NRs 5.77 billion, which measures the Investment, ranks $101^{\text {th }}$ largest in the world (World Bank 2017). The working of production factors in the economy has resulted in the GDP of NRs 749.6 billion, which ranks $102^{\text {nd }}$ out of 196 countries (World Bank, 2017).So, although there are ample resources, viz labour force and arable land, Nepal is still among the world's poorest countries with the Human Development Index ranked $147^{\text {th }}$ out of 189 countries (UNDP 2018). This may be attributed to the fact that though two-third of the labour force participates in the agriculture, agriculture contributes less than onethird of the national GDP, inferring low productivity in agriculture, thereby lower income to farmers, resulting in lower standard of living (UNDP 2018). Despite low agriculture share in GDP, for the agriculture-dominated country like Nepal, the arable land and labour availability play a major role in determining GDP (Mongus et al. 2012; Lawal 2011; Ogen 2007). Similarly, besides land and labour, the capital formation measured through GFCF is an important component of national income because the improvement in land, equipment purchases, construction of roads and other buildings help produce a higher amount of goods and services than before (Cohen et al. 2012). Thus, on aggregate agricultural land, working force and GFCF are the major components affecting the GDP in the Nepalese context.

Early research (Ra \& Rhee, 2005; Khanal \& Sharma 1992) focused on determining Nepal Macro econometric Model variables and found political stability and inflow of foreign borrowing to influence the GDP. The research by Adhikari (2017) determined that government expenditure on agriculture contributes significantly to GDP, whereas domestic savings and foreign direct Investment on agriculture were found insignificant by using Ordinary Least Square Method (OLS). In Nigeria, Solomon et al. (2019) found the GDP affected directly by food production level and government expenditure on agriculture by using Vector Error Correction Model (VECM). Similarly, by using VECM, equilibrium relationships exist between capital formation, human capital and economic growth rate (Adhikary 2015). According to Joshi et al. (2019), investment has a significant positive impact on economic growth by using ARDL method. Similarly, Chaudhary (2017) estimated the aggregate consumption function, one of the significant components of national income, using Autoregressive Distributive Lag (ARDL) method and found short run and long run relationships between consumption, real income, real interest rate, inflation rate and exchange rate.

\section{MATERIALS AND METHODS}

The study was conducted based on the secondary information collected from reports of governmental and international organisations to study and analyse the numerical contribution of factors of production on national income. The time-series data from 2000/012017/18 were collected and the data included agricultural 
land area collected from Statistical Information on Nepalese Agriculture yearbook by Ministry of Agriculture and Livestock Development (MoALD), working force collected from World Bank report and GFCF, and real GDP at basic price collected from Economic Survey reports by Ministry of Finance (MoF). The data from GDP and GFCF were calculated at constant price of 2000/01. The information collected helped to know the trend and growth rate of various variables set. The use of GDP as dependent variable and agricultural land, working force and GFCF as independent variables were regressed using Cobb-Douglas function specified as

$\operatorname{lnGDP}=\alpha+\beta_{1}$ LnAgriLand $+\beta_{2}$ LnWorkForce $+\beta_{3}$ LnGFCF $+\mu_{t}$

Where,

LnGDP $=$ logarithm of GDP

LnAgriLand $=$ logarithm of agriculture area land

LnWorkForce $=$ logarithm of working force population

$\mathrm{LnGFCF}=$ logarithm of GFCF

$\mu_{\mathrm{t}}=$ error term

The model was analysed through Stata software (Version 12.1), and the findings were interpreted with appropriate graphs and tables.

\section{RESULTS AND DISCUSSION}

\subsection{Trend of GDP, Agriculture Land, Working Force and GFCF}

The trend line data showed that at 2000/01, the real GDP was NRs. 413.14 Billion, which started growing at a steady rate over time, but in 2015/16, it flattened due to earthquake occurrence resulting in losses of infrastructure, buildings and people (MoF 2018). After that, GDP skyrocketed the past few years, reaching NRs 796.78 Billion in 2017/18, as shown in Figure 1.

$n \backslash \mathrm{s}$

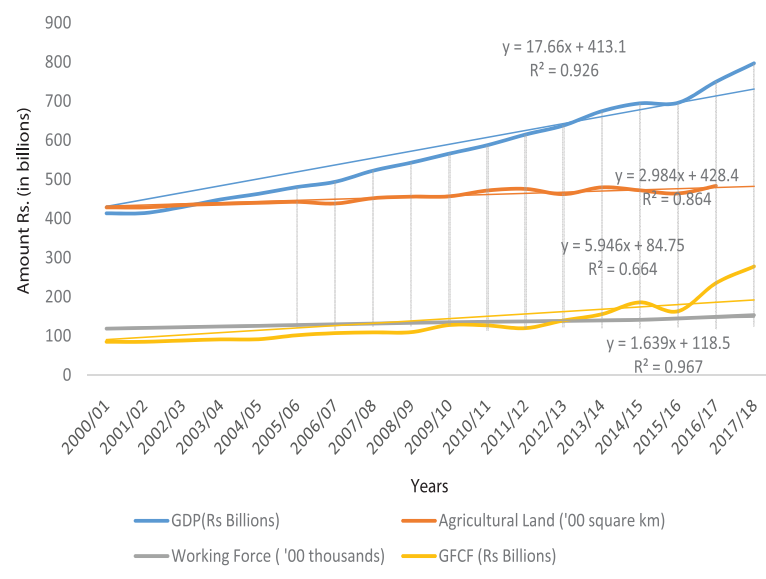

(Source: MoF, 2018; MoALD, 2018; World Bank, 2018)
Fig. 1. Timeline of GDP, Agricultural Land, Working Force and GFCF

The agricultural land area in 2000/01 was $42,844.14$ sq. km and grew slowly to $48,337.01 \mathrm{sq}$. $\mathrm{km}$ in $2016 / 17$ with fall in area from previous years in 2001/02, 2006/07, 2012/13 and 2015/16.Similarly, the working force in 2000/01 was 11.85 million and reached to 15.31 million in $2017 / 18$ with an increasing trend over time. Moreover, finally, the Gross Fixed Capital Formation (GFCF) was NRs 84.75 billion in 2000/01 reaching NRs 277.58 billion in 2017/18 with the general increasing trend but plummeted during 2010/11, 2011/12 and 2015/16. Thus, during 2015/16 except the working force, every other variable took hit in their declining order values.

\subsection{Growth rate trend of GDP, Agricultural Land, Working Force and GFCF}

The average GDP growth rate during 2001/02 to 2017/18 was $3.95 \%$ reaching all time low at $0.2 \%$ in $2001 / 02$ and 2015/16 and reaching all time high in 2016/17 (7.7\%). Similarly, average growth rate of agricultural land $(0.77 \%)$ and working force $(1.52 \%)$ was found to be lower compared to the GFCF $(7.90 \%)$ as shown in Figure 2, but the deviation was observed maximum in GFCF $( \pm 12.86 \%)$ and minimum in working force $( \pm 0.67 \%)$. The results are shown in Table 1.

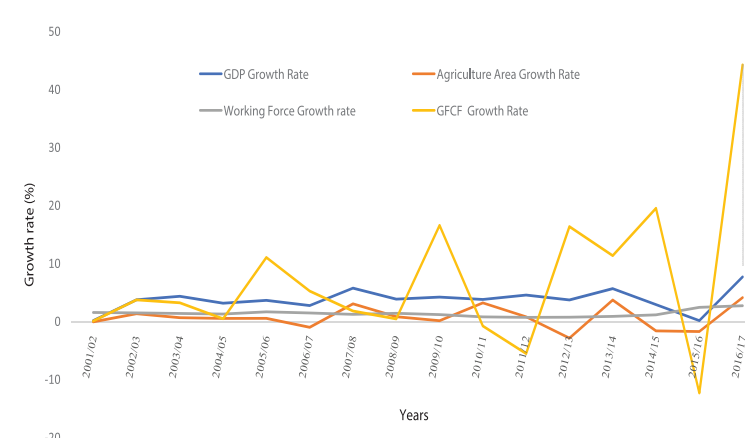

(Source: Author's Calculation)

Fig. 2. Timeline of Growth Rate of GDP, Agricultural Area, Working Force and GFCF

The agricultural land variable's highest growth rate was found in 2016/17 (4.16\%) and negative in 2012/13 $(-2.81 \%)$. The highest growth rate of labour force was found in 2017/18 (3.03\%) and minimum in 2011/12 $(0.75 \%)$. Finally, the GFCF was found maximum in $2016 / 17$ (44.28\%) and minimum/negative in 2015/16 $(-12.28 \%)$. 
Table 1: Descriptive Analysis of growth rate of GDP, Agricultural Land, Working Force and GFCF

\begin{tabular}{|l|l|c|c|c|c|}
\hline SN & Variable & Mean & Std. Dev. & Min & Max \\
\hline 1 & GDP growth rate & 3.95 & 1.91 & 0.20 & 7.74 \\
\hline 2 & Agriculture Land growth rate & 0.78 & 2.01 & -2.82 & 4.17 \\
\hline 3 & Working Force growth rate & 1.52 & 0.66 & 0.75 & 3.03 \\
\hline 4 & GFCF growth rate & 7.90 & 12.86 & -12.28 & 44.28 \\
\hline
\end{tabular}

\subsection{Determinants of GDP}

Using Cobb-Douglas regression, we found log of agricultural land and log of working force significantly affected the log of GDP, while log of GFCF was rejected at a $5 \%$ level of significance. Thus, in other words, with a $1 \%$ increase in agricultural land, GDP increased significantly by $1.13 \%$, while other variables remained constant. Similarly, with $1 \%$ increase in working force population, GDP increased significantly by $1.71 \%$, while other variables remained constant as shown in Table 2.

Table 2: Cobb-Douglas Regression of GDP and Its Determinants

\begin{tabular}{|l|c|c|c|c|c|}
\hline \multicolumn{1}{|c|}{ Source } & SS & df & MS & Number of obs $=$ & 17 \\
\hline \multicolumn{1}{|c|}{} & & F $(3,13)=$ & 342.35 \\
\hline Model & .604531897 & 3 & .201510632 & Prob $>$ F $=$ & 0.0000 \\
\hline Residual & .007651945 & 13 & .000588611 & R-squared $=$ & 170.9875 \\
\hline & & & & Adj R-squared $=$ & 0.9846 \\
\hline
\end{tabular}

\begin{tabular}{|l|c|c|c|c|c|c|}
\hline Total & .612183842 & 16 & .03826149 & Root MSE $=$ & \multicolumn{2}{|c|}{.02426} \\
\hline & & & & & \multicolumn{2}{|c|}{} \\
\hline LnGDP & Coef. & Std. Err. & $\mathrm{t}$ & $\mathrm{P}>|\mathrm{t}|$ & \multicolumn{2}{|c|}{$[95 \%$ Conf. Interval] } \\
\hline LnAgriLand & 1.135287 & .420287 & 2.70 & $0.018^{*}$ & .227312 & 2.043262 \\
\hline LnWorkingForce & 1.71294 & .3895133 & 4.40 & $0.001^{* *}$ & .8714478 & 2.554433 \\
& & & & & & \\
\hline LnGFCF & .1393072 & .0658851 & 2.11 & 0.054 & -.0030288 & .2816432 \\
\hline Constant & -34.62751 & 4.561363 & -7.59 & 0.000 & -44.48173 & -24.77328 \\
\hline
\end{tabular}

\section{CONCLUSION}

Among all the production factors, GDP was affected considerably by agricultural land and labour, while GFCF didn't influence it. Since Nepalese GDP is dependent on remittance and imports, thereby money is spent on purchasing consumer goods rather than the production of goods, as a result GFCF didn't influence much in GDP. Thus, to boost or improve Nepalese economy, the government must focus on expanding agriculture area by utilizing uncultivated land, increasing cropping seasons, and fast-tracking High Value Crops. Besides land, in the context of labour, the government must focus its efforts on increasing employment rate, so that the labour force participation rate is increased. It can be done by providing the Nepalese people with qualitative and globally time demanded skills and qualification.

\section{ACKNOWLEDGEMENT}

We would like to provide our sincere appreciation for the Agriculture and Forestry University's learning opportunities at Chitwan, Nepal. This paper and the research behind it would not have been possible without the exceptional support of our colleagues, Anish Shakya and Nobel Acharya for aiding in collecting the secondary data to accomplish this study.

\section{REFERENCES}

1. Adhikari, S. 2017. Contribution of the agriculture sector to the national economy in Nepal, Journal of Agriculture and Environment. 16:180-187.

2. Adhikary, B. K. 2015. Dynamic effects of FDI, trade openness, capital formation and human capital on the economic growth rate in the least developed economies: evidence from Nepal. International Journal of Trade, Economics and Finance. 6:1-7. 
3. Ahuja, H. L. 2018. Macroeconomics theory and policy. Twentieth edition. S Chand \& Company Ltd, Uttarakhand, India.

4. Chaudhary, A. 2017. Estimation of aggregate consumption function for Nepal: ARDL bound testing approach. Nepal Rastra Bank Economic Review. 29:51-65.

5. CIA. 2017. In the world factbook. Retrieved from https://www.cia.gov/library/publications/the-worldfactbook/geos/np.html.

6. Cohen, I., T. Freiling and E. Robinson. 2012. The economic impact and financing of infrastructurespending. Retrieved from http://www. wm.edu/as/publicpolicy/documents/prs/aed.pdf.

7. Deepashree, D.2016. Introductory macroeconomics. New Saraswati HousePvt. Ltd., New Delhi, India.

8. Gertner, J. 2010, 10th May. The rise and fall of the GDP. The New York Times. https://www.nytimes. com/2010/05/16/magazine/16GDP-t.html.

9. IMF. 2001. Macro-economic policy and poverty reduction. International Monetary Fund, working paper No. WP/01/135.Available at:https:/www.imf. org/external/pubs/ft/wp/2001/wp01135.pdf

10. Joshi, A., S. Pradhan and J.P. Bist. 2019. Savings, Investment, and growth in Nepal: an empirical analysis. Financial Innovation. 5:1-13.

11. Khanal, D.R. and G.N. Sharma. 1992. A macroeconometric model of Nepal in SAARC link. Oxford and IBH Publishing Co. Pvt. Ltd., New Delhi, India.

12. Lawal,W.A. 2011. An analysis of government spending on agriculture sector and its contribution to GDP in Nigeria. International Journal of Business and Social Science. 2:244-250.

13. Maharjan, A. and S. Bauer. 2012. International migration, remittances and subsistence farming: evidence from Nepal. International Migration. 1-15

14. Marshall, A. 2009. Principles of economics. Eighth edition. Cosimo Inc., New York, USA.

15. MoALD. 2018. Statistical information on nepalese agriculture. Ministry of Agriculture and Livestock Development, Kathmandu, Nepal.
15. MoF. 2018. Economic survey. Ministry of Finance, Kathmandu, Nepal.

17. Mongus, T., B. Yu, S. Fan and L. McBridge. 2012. The impacts of public Investment in and for agriculture, synthesis of the existing evidence. Food and Agriculture Organization working paper No. 12-07. Available at: http://www.fao.org/3/a-ap108e.pdf.

18. Ogen, O. 2007. The agricultural sector and Nigeria's development: comparative perspective from Brazilian agro-industrial sector economy, 1960-1995. Nabula. 4:184-194.

19. Ojha, K.P. 2019. Remittance status and contribution to GDP of Nepal. NCC Journal. 4:101-112.

20. Paudel, N.S. 2015. Migration trend and remittance infow: the experience of Nepal. Tribhuwan University. Unpublished manuscript. Department of Economics, Tribhuvan University, Kathmandu, Nepal.

21 Ra, S. and C.Y. Rhee. 2005. Nepal macroeconometric model. Asian Development Bank, working paper No. 1. Available at: https://www.adb.org/sites/default/ files/publication/28683/wp1.pdf

22. Seddon, D., G. Gurung and J. Adhikari. 1998. Foreign labour migration and the remittance economy of Nepal. Critical Asian Studies. 34:19-40.

23. Solomon, E., O.G. Edet and I.U. Kyari. 2019. Econometrics analysis of impact of insecurity on agricultural growth and transformation in Nigeria (1960 - 2017). Direct Research Journal of Agriculture and Food Science. 7:264-270.

24. Sunam, R. and J.F. Mccarthy. 2015. Reconsidering the links between poverty, international labour migration and agrarian change : critical insights from Nepal. The Journal of Peasant Studies. 43:39-63.

25. Thoma, M. 2016. Why GDP fails as a measure of well-being. CBS News. Retrieved from https://www. cbsnews.com/news/why-gdp-fails-as-a-measure-ofwell-being.

26. World Bank. 2017. World bank data 2017. Retrieved from https://data.worldbank.org/indicator/AG.LND. ARBL.ZS?locations $=\mathrm{NP}$ 